\title{
A RECÉM-CRIADA COMISSÃO DAS ILHAS DA UGI E A SUA CONFERÊNCIA INAUGURAL (TAIPEI, 2007)
}

EdUARDo BRITO HENRIQUES ${ }^{1}$

A União Geográfica Internacional (UGI) decidiu em 2006, na reunião de Brisbane, instituir duas novas comissões, uma dedicada aos estudos insulares - a Comissão das Ilhas (C04.36), presidida pelo Prof. Chang-yi David Chang (Universidade Nacional de Taiwan, China-Formosa) e tendo como Secretária a Prof. ${ }^{a}$ Huei-Min Tsai (Universidade Normal Nacional de Taiwan, também da China-Formosa), e a outra dedicada aos Direitos e Conhecimentos dos Povos Indígenas (C04.35), a que preside o Prof. Jay T. Johnson (Universidade do Nebrasca, EUA). A constituição em simultâneo destas duas comissões não terá sido casual. À sua formação superintenderam razões bastante mais próximas do que à primeira vista poderá transparecer. Ambas, embora de diferentes formas, correspondem à consagração do pensamento pós-colonialista entre as 'sensibilidades autorizadas' da Geografia, ou, por outras palavras, à sua 'institucionalização’.

A chancela do pós-colonialismo aplicada ao mundo académico delimita uma área de estudo focalizada na análise e na reflexão sobre os efeitos da colonização e do imperialismo nas sociedades, nas culturas e nos lugares. Inspirada no pensamento de autores como Edward Said, Homi Bhabha e Stuart Hall, a abordagem pós-colonialista procura compreender como o passado colonial continua a determinar no presente (ou seja, mesmo em contextos pós-coloniais) as estruturas de poder e a vida social, quer nas 'metrópoles', quer nas 'colónias', e o modo como ele se interpõe na relação entre as pessoas e os grupos humanos susceptíveis de se definirem em termos de 'colonizadores' e 'colonizados'. O pós-colonialismo tem depois ainda, enquanto projecto científico, a pretensão de conseguir superar esse modo de ver intrinsecamente desigual, introduzindo nas ciências sociais uma outra forma de abordagem alternativa, estruturada a partir do ponto de vista dos grupos que foram 'desempoderados' pelo colonialismo.

Essa marca do pós-colonialismo está muito patente e é facilmente detectável na Comissão sobre os Direitos e Conhecimentos dos Povos Indígenas. Na Comissão das Ilhas, a influência do pensamento crítico pós-colonial talvez não seja, num primeiro relance, tão perceptível, mas não deixa de estar igualmente presente. As ilhas ocupam no mundo actual, enquanto territórios, um lugar semelhante ao ocupado pelos povos indígenas, enquanto grupos humanos. A relação das ilhas com os espaços não insulares, ou, no caso das configurações geopolíticas arquipelágicas, das 'pequenas ilhas' com as

1 Professor Auxiliar da Universidade de Lisboa. Investigador do Centro de Estudos Geográficos. E-mail: eduardo.b.h@fl.ul.pt 
'grandes ilhas' (mainlands), tem sido persistentemente moldada ao longo da história na assimetria de uma relação de pertença-posse, ou de dominado e dominador, que no fundo traduz a essência do colonialismo. Mesmo desvantagens que tendemos a considerar 'naturalmente' inerentes às ilhas, como a perificidade relevam na verdade de um ponto de vista que foi sendo historicamente construído — o das mainlands, sendo portanto produtos de uma relação de poder assimétrica em que certos lugares se assumiram como centros e remeteram outros para a condição de periferia.

Tal como a recém-criada Comissão da UGI dos Povos Indígenas pretende dar voz às sociedades e culturas que o colonialismo silenciou (e não apenas o colonialismo europeu, nem apenas o dos séculos XIX e XX), também a criação da jovem Comissão das Ilhas procura trazer para o foco da investigação geográfica espaços que ao longo dos tempos se viram remetidos para uma posição marginal e secundária por força de relações de tipo colonial e que, em parte por isso, mas em parte também pelas suas próprias condições naturais, se encontram marcados por vulnerabilidades muito próprias e justificam cuidados especiais. A Conferência Inaugural da Comissão, decorrida no moderno Centro Internacional de Congressos da Universidade Nacional de Taiwan, em Taipei, entre 29 de Outubro e 3 de Novembro de 2007, espelhou esse objectivo nos temas que abordou. As comunicações apresentadas sintetizam bem as preocupações actuais dos estudos insulares e deixam antever quais serão, nesta área, as principais orientações da pesquisa no futuro mais próximo.

O programa de trabalhos da conferência, impecavelmente preparada pelos organizadores chineses, compreendeu três dias de trabalho intenso, repartidos entre comunicações e estimulantes debates. As pausas entre as sessões foram aproveitadas para a apresentação de novidades bibliográficas e projecção de filmes documentários alusivos aos temas em debate. Os últimos três dias do encontro juntaram os delegados da Comissão das Ilhas e da Comissão dos Direitos e Conhecimentos dos Povos Indígenas, cuja reunião inaugural decorreu em paralelo, tendo sido dedicados a uma visita de estudo ao Parque Nacional Taroko, onde foi organizado um 'seminário de campo' com a participação de membros da comunidade indígena local. O parque nacional visitado, situado nas montanhas da costa oriental da Formosa, acolhe uma das principais nações aborígenes da ilha (povos não chineses) — os taroko, etnicamente próximos dos povos polinésios do Pacífico, como os maori da Nova Zelândia e os rapanui da ilha da Páscoa, e que constituem no presente, com as outras nações aborígenes que sobrevivem na Formosa, uma minoria de cerca de 300.000 habitantes.

$\mathrm{O}$ primeiro dia de trabalhos foi dedicado à discussão de questões mais teóricas relativas as estudos insulares. A sessão da manhã, intitulada 'Novos Horizontes da Pesquisa Geográfica', dedicou-se à reflexão sobre o lugar dos estudos insulares nas orientações actuais da investigação dos geógrafos. A sessão foi inteiramente ocupada por conferências a cargo de key speekers convidados. Falaram Ronald A. Abler (Vice-presidente da UGI), Anne Buttimer (Universidade College de Dublim, Irlanda) e Paul Claval (Universidade de Paris-Sorbonne, França). Ronald A. Abler fez um discurso institucional, sobre o papel que se espera que as duas novas comissões venham a ter na vida da UGI. Anne Buttimer procurou ligar os estudos insulares às problemáticas do desenvolvimento sustentável, chamando a atenção para o facto da 'escala' das ilhas colocar muitas vezes limitações à desejada conciliação dos interesses económicos, sociais e ambientais, e com isso suscitar problemas muito diferentes daqueles que se observam em outros espaços; em consequência disso, aconselhou a que o desenvolvimento sustentável das ilhas fosse objecto de uma atenção muito particular por parte dos investi- 
gadores. Paul Claval, por seu turno, depois de fazer uma breve história cultural da representação das ilhas no Ocidente, defendeu a necessidade de evitar abordagens dos espaços insulares que sejam modeladas pela visão do exótico, e de que em alternativa se façam assentar os novos estudos das ilhas na perspectiva de quem habita nelas, ou seja, numa fenomenologia da experiência da insularidade.

Foi no essencial ao encontro desta ideia de Paul Claval que vieram as várias comunicações apresentadas na sessão seguinte, intitulada 'Concepções dos Estudos Insulares'. Tomaram a palavra nesta sessão, com comunicação, autores que têm estado na linha da frente da teoria dos estudos insulares, ou nissologia, como Godfrey Baldacchino (Universidade da Ilha do Príncipe Eduardo, Canadá) e Grant McCall (Universidade de Nova Gales do Sul, Austrália), ambos insistindo na ideia de que a novidade da nissologia deverá residir em privilegiar-se a perspectiva até agora sempre secundarizada das próprias ilhas e dos povos insulares. Stephen A. Royle (Universidade de Belfast, Reino Unido), na mesma linha, mostrou como 'desvantagens' normalmente associadas aos espaços insulares, tais como a perificidade, o isolamento, a falta de recursos, etc., também podem ser perspectivadas, do ponto de vista das ilhas, como 'vantagens', enquanto recursos potencialmente mobilizáveis para actividades e formas de desenvolvimento alternativos. Muito interessante foi ainda a comunicação de Philip E. Steinberg (Universidade do Estado da Florida, EUA) sobre novas formas de habitar os espaços marítimos, nomeadamente as cidades flutuantes da Holanda e os cruzeiros residenciais, experiências que, como o autor bem mostrou, representam reinvenções do viver em comunidades de tipo insular.

As restantes comunicações apresentadas organizaram-se em torno de três problemáticas fundamentais: o lugar das ilhas no sistema de fluxos do capitalismo global, grande domínio temático em que o turismo ocupou um lugar crucial; os desafios ambientais com que se confrontam as ilhas, sobretudo em face da perspectiva de um aquecimento global; e a identidade, a memória e o sentido de comunidade nos espaços insulares.

A questão do lugar das ilhas no capitalismo global e da sua integração nas grandes redes de fluxos foi tratada em duas sessões, uma intitulada 'Geografia Política e Social das Ilhas' e a outra, 'Turismo Insular'. Na primeira sessão, trouxeram-se ao congresso interessantes comunicações que mostraram como é desadequada a imagem preconcebida das ilhas como 'espaços de isolamento', opondo a isso a constatação de que estas jogam um papel crucial como pontos de cruzamento de diferentes tipos de fluxos gerados pelas dinâmicas do capitalismo global, desde o turismo de massas internacional às migrações de trabalho sazonais informais (caso das comunicações de Antoni-Albert Artigues da Universidade das Ilhas Baleares, Espanha, de Costis Hadjimichalis da Universidade Harokopio de Atenas, Grécia, ou de Eric Clark da Universidade de Lund, Suécia). A segunda sessão baseou-se fundamentalmente na apresentação de estudos de caso sobre os efeitos do turismo na transformação dos espaços insulares, tendo sempre presente o 'turismo sustentável' por horizonte de referência. Merece neste grupo particular destaque a comunicação de Peter Billing (Centro de Investigações Regionais e de Turismo de Bornholm, Dinamarca) sobre um modelo de análise comparativo da competitividade e sustentabilidade turística das ilhas europeias em cujo desenvolvimento o autor tem estado a participar.

Aos problemas ambientais foram dedicadas também duas sessões. O problema da conservação dos ecossistemas insulares, que são por norma frágeis e têm uma biodiversidade reduzida, e o aquecimento global, com todas as consequências que pode trazer para os espaços insulares, foram os temas mais abordados, mostrando a forte preocupação 
que estes assuntos suscitam hoje na comunidade científica. As ilhas, e sobretudo as pequenas ilhas baixas, são dos territórios mais vulneráveis ao aquecimento global, quer pelo que ele significa em termos de uma hipotética subida do nível médio das águas do mar (redução da superfície das terras emersas, perda de biodiversidade, contaminação dos aquíferos pela água salgada, etc.), quer pela possibilidade de aumento da frequência de acontecimentos climáticos extremos, a que as ilhas são também por norma mais vulneráveis. Alguns destes problemas são já perceptíveis em diversos territórios insulares, nomeadamente do Pacífico, como mostraram, por exemplo, as comunicações de Beatte Ratter (Universidade de Hamburgo, Alemanha) e de Shunsuke Nagashima (Universidade de Kagoshima, Japão). Alguns pequenos países correm inclusive o risco de desaparecerem totalmente num horizonte de 40 a 50 anos, caso venham a comprovar-se os cenários mais dramáticos de subida das águas do mar, o que levanta problemas políticos e éticos da maior complexidade: serão estas afinal as primeiras vítimas de um problema de escala global para cuja causa pouco contribuíram e contra o qual não podem sozinhos lutar. A maior parte dos oradores concordou que é irrelevante discutir se há evidências suficientes de que as causas do aquecimento global são antrópicas, ou até se essa tendência vai no sentido de uma evolução mais ou menos catastrófica num horizonte temporal mais ou menos curto. O fundamental parece ser actuar de imediato simultaneamente à escala local como global, seja colocando o problema das alterações climáticas na agenda política internacional, seja implementando medidas de ordenamento de território à escala local destinadas a diminuir os potenciais riscos decorrentes desse aquecimento global.

Os problemas da identidade, da pertença ao lugar e do sentido de comunidade em territórios insulares foram os temas aglutinadores do último conjunto de comunicações apresentadas. O estudo levado ao congresso pelo autor desta notícia mostrou que a experiência da 'maritimidade' e a percepção de 'pequenez' e 'aglutinação' constituem os elementos fundamentais na vivência da insularidade, e que isso modela um sentimento de pertença ao lugar e à comunidade aparentemente diverso daquele que se forma nos espaços continentais; outras comunicações, defendendo que as ilhas são, muito mais do que espaços de isolamento, espaços de relação e de trocas, deixaram no ar a ideia de que a originalidade das paisagens culturais das ilhas reside em grande medida no seu sincretismo. Merece por fim destaque a comunicação apresentada por Elaine Stratford (Universidade da Tasmânia, Austrália), na qual se procurou reflectir sobre a importância dos sentimentos de pertença e do sentido de lugar nas ilhas enquanto recursos ontológicos favoráveis a uma participação política mais intensa. A comunicação abriu caminho a que nos interrogássemos sobre se esse sentimento de pertença não terá efeitos em termos da quantidade e qualidade do 'capital social' que se produz nas ilhas, e, depois, se este não será afinal um recurso altamente valoroso que se poderá mobilizar para o desenvolvimento dos territórios insulares.

Os trabalhos desta conferência inaugural da Comissão das Ilhas decorreram num ambiente amigável e informal, de grande cordialidade, facto que facilitou muitíssimo as trocas de opiniões e experiências entre os delegados que participaram no congresso. O contacto entre geógrafos da bacia do Atlântico e do 'rim do Pacífico', que são comunidades normalmente com poucas relações entre si, constituiu um outro aspecto muito positivo da reunião.

O próximo encontro da Comissão das Ilhas decorrerá em Agosto de 2008, em Tunis, enquadrado no 31. ${ }^{\circ}$ Congresso Internacional de Geografia. 